\title{
ARBITRATION AGREEMENTS AND THE CONFLICT OF LAWS
}

\author{
RAYMOND J. HEILMAN
}

It is proposed to examine the method or methods of treatment by courts in the United States of the question of the enforceability of arbitration agreements in conflict of laws cases. The view here taken is that the problem should be regarded and treated as substantive- that it is substantive in any clear and workable conception of the use of the term. This is not to deny that the problem has procedural aspects but only to deny that it is solely procedural. It may be worthwhile to inquire whether enforceability has not in some instances been labelled a "procedural" matter, and placed under the rule that "questions of procedure are determined according to the I $\left(.\right.$, for $^{\prime}$." in order to effect the result which application of the rule of the forum would bring about. ${ }^{2}$ It is submitted that the rules which are applied to determine the validity or enforceability of the main agreement to which the arbitration provision relates should be applied to determine the validity or enforceability of the arbitration provision as well. This is the attitude taken by the English courts, although its adoption by those courts may be largely explained by the passage of the English Arbitration Act of 1889, by which arbitration stipulations in domestic cases were expressly declared valid and enforceable. In the United States, on the other hand, it should be borne in mind that the courts have in many instances, if not generally, taken an attitude of hostility toward arbitration, considering arbitration in the traditional manner as tending to "oust them of jurisdiction" or as usurping court functions.

The assertion that the domestic rule of the forum (lex fori) should determine whether or not a stipulation for arbitration is enforceable is often, if not usually, supported by a statement that such a stipulation is procedural or remedial, with a negative statement or implication that it is, therefore, not substantive. The distinction between that which is regarded as "substantive" and that which is regarded as "procedural" (or "remedial" or "adjective") is thought by the writer to present merely a differ-

: In such a case it could perhaps be said that the question was labelled "procedural" because it was felt to be "substantive," i. e., if it is accepted that "Substantive law is concerned with the ends which the administration of justice seeks, (while) procedural law deals with the means and instruments by which those ends are to be attained." S.ALMosd. Jurisprudence (6th ed. 1920) 438. 
ence of point of view in considering court action, or other societal action, with respect to a factual situation. One may consider such action primarily from the standpoint of the effect of what is done, or from the standpoint of the act or series of acts by which a certain effect is brought about. That is, it would seem that the terms "substantive" and "procedural" merely signify different sides of court or other societal action, and not generic differences between one type of societal action and another. And it is believed that it will be found that in most cases in which the distinction is drawn, it is made use of as an expedient or device to reach or to explain a particular conclusion or result. Whether or not arbitration be regarded as a remedy, a rule providing that arbitration shall be required, if stipulated for by the parties to a contract, causes certain legal relations to exist, including a right-duty relation with respect to the carrying out of the arbitration stipulation. Enforcement of an arbitration agreement "... a ffects substance and not merely procedure in that it determines the legal relations consequent upon the operative facts...." 2 Furthermore, to the extent that the arbitration agreed upon would treat of legal relations, enforcement of an agreement to arbitrate determines legal relations. $^{3}$ Also, submission to arbitration according to the terms of an agreement either may or may not constitute an operative fact determining the existence of a legal remedy, and consequently of one or more right-duty or other legal relations. It does not seem plausible, therefore, to say that such submission is totally non-substantive, nor that a legal rule requiring such submission is totally non-substantive."

2 CoRBin, CASES oN CoNTRACTS (1921) 1475n., referring to the statute of frauds; cf. Lorenzen, The Statute of Frands and the Conflict of Laws (1923) 32 Y ALE L. J. 311, 324: "'Substance' includes all rules determining the legal relations which the courts will declare when all facts have been made known to them. ..." See Chamberlayne, Evidence (1911) $\S 171$.

3 With reference to cases in which the award of an arbitrator has been expressiy made a condition precedent to the existence of any right of action, Professor Corbin has recently said: "We should not deny that an arbitrator is administering Legal Rights in cases falling within the principle enunciated by the House of Lords in Scott v. Avery. That was merely the case of a contract that created Conditional Legal Rights. The award of an arbitrator in such a case would determine the legal operation of the existing facts, even though a Cause of Action for damages or an injunction does not yet exist, if the question of their legal operation was within the submission agreement or court order. ..." Conditional Rights and the Functions of an Arbitrator (1928) 44 L. Q. REv. 24, 32.

1 The procedure in any given case in litigation in which remedial action by a court may be obtained may even be regarded as substantive in this respect that if the necessary procedural steps are taken a new substantive right-duty or other legal relation or relations will be created when the resulting judgment or decree is rendered. The procedural steps are opera- 
The questions which come up in a case involving an alleged contract may be classified as follows: (1) interpretation of the conduct of the parties (including their verbal or witten expressions) - a matter of ascertaining the operative facts; (2) the legal consequences thereof; (3) procedure-a matter of the machinery of the courts in litigation. A formalistic distinction or definition should not, however, be allowed to override or bury a consideration of policy, without regard to which the real problem in a case cannot have been settled as thoroughly as possible. The ends sought in settling different types of problems will require differing results, but these results should be franlly explained on the basis of the differences in the purposes predominantly sought to be served in each case, not on the fictitious basis of a mere abstraction.5 There is grave danger of overlooking this in conflict of laws cases, especially as regards the tendency to treat domestic cases and conflict of laws cases as if they were analytically and functionally alike. Not being even analytically identical, diversity rather than similarity of treatment from a functional standpoint is certainly to be expected. Yet the failure to bear the distinctness of each in mind, or a tacit assumption that they are or should be treated as in all respects the same, is a source of much misunderstanding and confusion of thought.6 Thus, "the term 'procedure' may have one meaning

tive facts to which legal consequences are attached. Procedural law can be translated into rights, duties, powers, liabilities, privileges, no-rights, immunities, disabilities. The only workable line of distinction, it seems to the writer, is between the legal consequences themselves, $i$. e., legal relations produced by the process of litigation, and the means, or machinery whereby such legal consequences are brought about or such legrl relations established. Confusion and inconsistency of treatment can be minimized only by excluding from treatment as merely procedural all that may possibly be regarded as substantive. Failure to adopt some such worling basis of differentiation, together with the lack of elear analysis, may have and probably has occasioned to a large extent the confusion and inconsistency of treatment to be noted in American cases dealing with statutes of limitations of different types and, to some extent, in those dealing with statutes of frauds. SALMroNd, op. cit. supra note 1, at 440: "The limitation of actions is the procedural equivalent of the prescription of rights. ..." LORENZEN, op. cit. supra note 2, at 381: "Analytically the statute of limitations and the statute of frauds present more or less the same problem. Upon principle both affect the substantive rights, duties, privileges, etc. of the parties." See also Comment (1919) 28 Yals L. J. 492.

5 LoRenzen, op. cit. supia. note 2, at 392: "We must beware lest we determine questions which should be controlled by considerations of policy by a purely mechanical process."

${ }^{6}$ See the following pioneer articles which show the fallacious analytical bases commonly underlying the treatment of conflict of laws problems by American writers and courts: Cook, The Logical and Legal Bases of the Confict of Laws (1924) 38 YALE L. J. 457; Lorenzen, Territorinlity, Public Policy and the Confict of Law' (1924) 38 YaLe L. J. 726. 
in matters of internal law, and a narrower meaning from the point of view of the Conflict of Laws." 7 Conceivably a rule or stipulation which may be treated as procedural for one purpose may with fitness be treated as substantive for another purpose. Furthermore, it is obvious that from a practical standpoint, the . extent to which an arbitration agreement is given effect may actually render the legal consequences of an agreement as a whole, entirely, partially or not at all what the parties manifestly stipulated for. The very object of the parties in providing for arbitration may have been to make sure that certain things be done, $i$. e., that certain consequences be attached, which might be, and very likely would be, different because of the arbitration than through litigation without arbitration. It was probably not contemplated that the results secured by arbitration would be regarded as objectionable as a matter of policy by a court which might have to deal with the controversy. Commercial arbitrators may be expected to have courses of conduct in view in dealing with matters familiar to them, and these may be totally dissimilar from those which a court composed of men out of touch with the particular kind of business concerned might have in view. Hence different conclusions and differing results may well be anticipated. The very differences to be anticipated in the results or, more specifically, the very result to be expected of arbitrators, as distinguished from the result to be expected from a court, may very likely have been exactly what occasioned the provision for arbitration. The results sought by the device of arbitration, it would seem, should ordinarily be given effect. It does not seem plausible to say that procedure alone, and not legal consequences, are dealt with, or that the legal consequences are the same whether or not arbitration provisions are enforced.

We are then brought to this question: what is the scope of the rule that "The lex for is applied to determine matters of procedure or remedy"? It is believed that this rule should be confined to questions of procedure arising in relation to the machinery of litigation. By this, it is not meant that the rule of the forum should never be applied as a substantive rule. The objection of the writer is to confusing substantive with procedural questions. If in a given case a particular court has to decide whether or not to hold an arbitration stipulation valid and binding upon the parties either before or after submission and arbitration, the question, being of the legal consequences of the stipulation, should be treated as substantive from the standpoint of the conflict of laws. In other words, the lex fori, under the

\footnotetext{
T.Lorenzen, op. cit. supra note 2 , at 330 .

8 Watson, 'L. J., in Hamlyn \& Co. v. Talisker Distillery, [1894] A. C. $202,213$.
} 
conflict of laws rule which is being considered, is not appropriate to determine the substantive effect of an arbitration stipulation or an arbitration already carried out, but is appropriate, if at all, only as a "curial rule" ${ }^{8}$ as to the mode of applying the machinery of the court for determining an issue which the court has seen fit to determine. To say that procedural law in conflict of laws cases is regulated by the law of the forum means that the law of the forum provides the machine through which the legal consequences are produced, and that alterations in the machine are not made when attending to a conflict of laws case. A conflict of laws case is put through the same mechanism or handling as a case that is alike in all respects except that it involves no conflict of laws question.

Dicey, in explaining the scope of the rule as applied by the English courts, says:

"The maxim that procedure is governed by the lex for means in effect that it is governed by the ordinary rule of England, without any references to any foreign law whatever. The maxim is in fact a negative rule; it lays down that the High Court, in common, it may be added, with every other English Court, pursues its ordinary procedure and adheres to its ordinary methods of investigation, whatever be the character of the parties or the nature of the cause which is brought before it. ... Whilst, however, it is certain that all matters which concern procedure are in an English Court governed by the law of England, it is equally clear that everything which goes to the substance of a party's rights and does not concern procedure is governed by the law appropriate to the case. ... Our Rule is clear and well established. The difficulty of its application to a given case lies in discriminating between matters which belong to procedure and matters which affect the substantive rights of the parties. In the determination of this question two considerations must be borne in mind:-

"First: English lawyers give the widest possible extension to the meaning of the term 'procedure'. The expression, as interpreted by our judges includes all legal remedies; and everything connected with the enforcement of a right. ...

Secondly, any rule of law which solely affects not the enforcement of a right but the nature of the right itself, does not come under the head of procedure."

While the use of the conflict of laws rule, that questions of procedure should be determined according to the local lule of the forum, to bring the question at hand under the local rule of the forum is unmistakably apparent, this has been carried to such an extent that considerations which should be regarded as of greater import have sometimes been disregarded. Thus, questions which it would seem desirable to treat as substantive have been swept under the rule that "the lei fori determines procedure." The tendency to apply this conflict of laws rule too widely

9 Dicey, CoNflict of Laws (Keith's 4th ed. 1927) 797. 
is no doubt given some further impulse by the failure of the judges to see clearly that in the final analysis a court can apply only its own law, whether or not the particular case has foreign elements. Concerning this tendency, Professor Lorenzen has made the following statements:

"From the standpoint of the Conflict of Laws there is the greatest need of restricting the term 'procedure' to its proper significance, for, according to the traditional rule in this subject, all matters of procedure are submitted to the law of the forum. English and American courts have been too prone to say in tho past that a particular matter belonged to procedure, and that it was controlled therefore by the law of the forum. They have given to the term a very wide meaning, with the consequence that many matters, which on principle and according to the established practice of other countries should be governed by some other law, are subjected to the law of the place where the suit happens to be brought. The reason for this attitude on the part of the Anglo-American courts is not far to seek. The tendency of the common law has always been to be exclusive. It is no wonder, therefore, that when the English courts were first asked to enforce rights 'created' by a foreign system of law, they should welcome any doctrines which would operate restrictively in the recognition and enforcement of such rights. They willingly accepted, therefore, the doctrine of the Dutch School which gave to the term 'procedure' a very extensive meaning. By subjecting to the law of the forum all matters belonging to procedure and giving that term the widest possible meaning, the field for the application of the 'foreign law' became necessarily reduced. . . .

"The wide meaning given to the term 'procedure' in the Conflict of Laws has already done much mischief. Our courts would do well to keep in mind the real meaning of the rule that all matters of procedure are governed by the local law of the forum. The sole object of the rule is to enable the courts to operate the judicial machinery in the customary manner. There are vast differences in the technical rules controlling the conduct of litigation under the systems of procedure prevailing in the different countries and any attempt to try a 'foreign' cause of action in accordance with the rules of the state or country in which it arose would be doomed to failure. A foreign litigant must therefore of necessity conform to the procedure of the court in which he seeks to enforce his claim. There is no reason, however, why a matter affecting the merits of the case or the operative effect of facts when once proved should not be controlled by the law governing the substantive rights of the parties, provided it is of a nature to pass conveniently and without ethical shock through the legal machinery of the forum. The label attaching to such matter from the standpoint of internal law matters little. It may be clearly 'substantive' or both 'substantive' and 'procedural' or possibly even exclusively 'procedural' as these terms may have been defined in the past." 10

Even with the very wide meaning which the English Courts have given to the term "procedure," for the purpose of applying

10 Lorenzen, op. cit. supra note 2 , at 327-332. 
the rule that matters of procedure should be determined according to the les fori, they have not gone so far as to determine the validity and enforceability of arbitration stipulations by the lex fori, but have decisively rejected and repudiated the contention that this should be done. As has been suggested, however, this might not have been the case in the absence of the existence in England of an internal rule favoring arbitration.

The English cases will now be briefly reviewed in order that the mode of treatment by the English courts of the enforceability of arbitration agreements in conflict of laws cases may be kept in mind in considering the American decisions. In the most infiuential English case, that of Hamlyn \& Co. v. Tuliskcr Distillery, ${ }^{11}$ an agreement entered into in England between a Scottish concern and a London company and performable in Scotland, included a provision for the arbitration of any dispute by two members of the London Corn Exchange, or their umpire. Action was brought in Scotland for breach of contract and the arbitration clause was set up in defense. According to the English local rule, the arbitration clause was enforceable as a part of the agreement; according to the local rule of Scotland the clause was invalid because the arbiters were not named. The Scottish Court of Sessions applied the Scottish rule, holding that the action was properly brought although arbitiation had not been had. This decision was reversed in the House of Lords, which held that the English rule was applicable to the agreement as a whole, including the arbitration provision and that the action was therefore not maintainable in absence of submission of the controversy to arbitration. As to the arbitration clause, Lord Herschell said:

"That clause is as much a part of the contract as any other clause of the contract." ${ }_{12}$

In rejecting a contention that "the rule of the for'um" ought to be applied, he said :

"It is argued that an agreement to refer disputes to arbitration deals with the remedy and not with the rights of the parties, and that consequently the forum being Scotch the parties cannot by reason of the agreement into which they have entered interfere with the ordinary course of proceedings in the Courts of Scotland. Stated generally, I should not dispute that proposition so far as it lays down that the parties cannot, in a case where the merits fall to be determined in the Scotch Courts, insist, by virtue of an agreement, that those courts shall depart from their ordinary course of procedure. But that is not really

${ }^{11}$ Supra note 8 . "This is a particularly strong case as it was decided by the House of Lords, when sitting as a Scottish Court of Appeal with regard to an action brought in Scotland." IICEY, op. cit. supia note $\mathbf{9}$, at 612.

12 Hamlyn \& Co. v. Talislier Distillery, sujuris note 8, at 207. 
the question which has to be determined in the present case. The question which has to be determined is whether it is a case in which the Courts of Scotland ought to entertain the merits and adjudicate upon them." 18

It should be observed, also, that the decision of the Scottish court below, that the local Scottish rule ought to be applied, was based not on the ground that the proper rule was the rule of the forum (lex fori) but on the ground that the rule of the place of performance (lex solutionis), $i$. e., of Scotland, ought to be applied.

In Spurvier v. La Cloche, ${ }^{14}$ an action was brought in a Jersey court by a Jersey resident, La Cloche, against the agents of an English insurance company, under a fire insurance policy executed in Jersey in the English language. By a provision of the policy, "the claim should, if not admitted, be referred to arbitration ... and ... the claimant should have no right of action against the company except for the amount of the claim, if admitted, or the amount, if any, awarded. . .." La Cloche had appointed one arbitrator to determine his claim, and the company another, but the appointed arbitrators had not designated an umpire as the arbitration agreement required. Dismissal of the action was sought on the ground that the requirement of arbitration and the rendition of an award had not been carried out. The claimant contended that the arbitration provision was contrary to the law of Jersey (the lex fori) and therefore of no effect. The Royal Court of Jersey, without comment, gave judgment in favor of the claimant. The decision was reversed in the House of Lords. The enforceability of the entire agreement including the arbitration provision was treated as determinable according to the rules of English law. The contention that the usual Jersey rule, by which the arbitration provision would have been held invalid, was appropriate of application, does not seem to have been rested upon the ground that the rule of the for'um ought to be applied. Jersey, besides being the forum, was the place of contracting, and may have been contemplated as the place of performance as well, though the court applied the English domestic rule upholding the enforceability of the arbitration stipulation.

In Pena Copper Mines, Ltd. v. Rio Tinto Co., Ltd., ${ }^{\text {t5 }}$ the agreement provided that it was to be construed as a contract made in England, in accordance with the law of England, "and that the rights, duties or liabilities of the parties should be referred to arbitration in conformity with the provisions of the Arbitration Act, 1889, the award of the arbitrators to be a condition

\footnotetext{
13 Ibid. 210.

14 [1902] A. C. 446.

15 105 L. T. R. 846 (1912).
} 
precedent to any liability of either party." The two companies were English companies operating in Spain. The Rio Tinto Co. had made a contract with a Belgian company which had assigned its rights, etc. to the Pena Copper Mines with the assent of the Rio Tinto Co. Both the original contract and the assignment seem to have been executed in Spain. The Court of Appeal sustained the issuance of an interim injunction to restrain the defendants, who had unsuccessfully brought an action in England, "from proceeding with an action in Spain on the contract." 'speaking for the court, Fletcher Moulton, L. J. said:

"In the present case by bringing an action in the Spanish Court, the Rio Tinto Company are depriving the Pena Company, the plaintiffs in the present action, of the right to apply to our courts to prevent this dispute from being decided in any other way than by arbitration. Therefore, we ought to exercise our powers in personam to prevent that line of conduct taking effect which is certainly contrary to their contractual duties." $1:$

Similar effect has been given in England to agreements to refer disputes to a foreign court instead of to arbitration. ${ }^{18}$ In the Cap Blanco, ${ }^{19}$ a bill of lading provided that any disputes as to its interpretation were "to be decided in Hamburg according to German law." The Court of Appeal held that the proceeding in England must be stayed in order that the parties might litigate in Germany.

One of the cases cited by counsel was Law v. Garrett, ${ }^{\prime 0}$ in which several British subjects, two of whom resided in England, executed and registered in Russia an agreement pertaining to the carrying on of a "partnership business" there, which provided that "all disputes, . . . shall be referred to the St. Petersburg Commercial Court (and) the decision of such court shall be final." The defendants were held to be entitled, under section 11 of the Common Law Procedure Act, 1854, to an order on their motion for a stay of proceedings in the action commenced in England, and a reference to the tribunal mentioned.

In Austrian Lloyd Steomship Co. v. Gresham Life Assurance Soc., Ltd., ${ }^{21}$ an appeal was allowed against an order refusing to

${ }^{16}$ DICEY, op. cit. supra note 9 , at 363 .

17 Pena Copper Mines, Ltd. v. Rio Tinto Co., Ltd., stupra note 15, at 852. The Lord Justice added that the question was one of "discretion."

Is DICEY, op. cit, supra note 9, at 549n: "At one time efiect would not be given to arbitration clauses wherever made, as ousting the jurisdiction of the courts of England. But since the Arbitration Act, 1889, which again repeated provisions of the Common Law Procedure Act, 1854, this is no longer the case. MForeover, agreement to refer to a foreign court will be allowed as a valid ground for staying an action in England."

19 [1913] P. 130.

208 Ch. D. 26 (1878),

21 [1903] 1 K. B. 249. 
stay proceedings in an action on a policy of life insurance effected by a foreigner, a native of Trieste, with an English company at Budapest. The policy, which was written in the French language provided that "For all disputes which may arise ... all the parties interested expressly agree to submit to the jurisdiction of the Courts of Budapest." The provision was held to constitute a "submission" under section 4 of the Arbitration Act of 1889.

It is clear from the above decisions that, in determining whether or not an arbitration agreement is to be enforced in conflict of laws cases, the English courts have not applied the normal rule of the forum, $i$. e., the rule corresponding with the domestic rule of the forum, but have dealt with the conflict of laws questions of the enforcement of arbitration provisions in the same way that they have generally dealt with conflict of laws questions of the enforceability of other contract provisions. With this background the discussion of the American cases may now be undertaken.

The decision and opinions in the New York Court of Appeals case of Meacham $v$. Jamestown, Franklin \& Clearfield R. R. ${ }^{2 a}$ are of interest as revealing apparent differences in the bases of treatment by the judges, and as illustrating modes of treatment often observable in conflict of laws cases, particularly the failure to differentiate such cases from those which are entirely domestic or intra-territorial. The controversy related to an arbitration provision in a railroad construction contract, by which a certain chief engineer was made arbiter of all disputes that might arise. The action was brought to recover from the defendant railroad, a Pennsylvania corporation, a sum of money which the plaintiff claimed as assignee for work done and materials furnished by another Pennsylvania corporation. The agreement was effected in Ohio. The submission which the arbitration provision called for had not been made.

The trial court held that the contract in question was to be performed in the state of Pennsylvania, and since the law of that state holding the contract valid and enforceable governed, the plaintiff could not succeed in his action for the reason that submission to arbitration was a valid condition precedent which had not been complied with. This decision was unanimously affirmed by the Appellate Division, but was reversed by the Court of Appeals. There were two concurring opinions differing totally in the explanatory basis for the result, and it is impossible to say with which of the differing views expressed by Judge Hogan and Judge Cardozo the majority of the concurring judges agreed. The former treated the question of the validity and enforcement of this arbitration clause as substantive, and op-

22211 N. Y. 346, 105 N. E. 653 (1914). 
posed enforcement on the ground that the clause was "an attempt ... to enter into an independent covenant or agreement to provide for an adjustment of all questions of difference arising between the parties by arbitration to the exclusion of jurisdiction by the courts." Arbitration clauses in domestic cases had been held invalid in New York. Judge Hogan said:

"Notwithstanding the decisions of the Court of Pennsylvania that the contract as to arbitration was valid and enforceable in that state, judicial comity does not require us to hold that such provision of a contract which is contrary to a declared policy of our courts shall be enforced as between non-residents of our jurisdiction in cases where the contract is executed and to be performed without this state, and denied enforcement when made and performed within our state." 23

There is no logical necessity that the "policy" pointing toward a particular result in a domestic case shall be carried over as the ground of decision of a case involving extra-territorial elements. To say that such logical necessity exists is to assume the identity of the two types of cases and to fail to apprehend, or else to ignore, that conflict of laws cases, as distinguished from domestic cases, may involve additional and distinct economic or social considerations of importance. The significance of the distinctiveness of each of these two types of cases evidently was not clearly seen in the MLacham case, for it would seem from the approval by Judge Hogan of the decision in Delavere \& Hudson Canal Co. v. Peninsylvania Coal Co.," a case in which only domestic questions were regarded as at issue, that he would have welcomed some basis on which to distinguish the Mcucham case from domestic decisions announcing the "declared policy" referred to above. In the case referred to by Judge Hogan, an arbitration agreement was upheld on "a distinction made between the provisions of a contract, providing that before a right of action shall accrue certain facts shall be determined, or amounts or values ascertained, and an independent covenant or agreement to provide for the adjustment and settlement of all disputes and differences by arbitration to the exclusion of the courts." 25 That distinction was studiously made, apparently for the purpose of holding submission to arbitration and rendition of an award necessary before action could be brought. Judge Hogan said further that "in subsequent decisions the distinction thus pointed out had been recognized and approved," ${ }^{26}$ citing only cases which were wholly domestic or were so treated. He seems to have based his conclusion on the assumption that, of necessity, the

23 Ibid. 351, 105 N. E. at 655.

2450 N. Y. 250 (1872).

25 Meacham v. Jamestown, Franklin \& Clearfield R. R., supra note 22, at 350,105 N. E. at 654 .

${ }_{26}$ Ibid. 351,105 N. E. at 654 . 
policy or rule put into effect in a domestic decision is to be treated as a precedent in a conflict of laws case involving the enforcement of an arbitration stipulation; or else to have failed to discern any essential difference between the two types of cases.

Judge Cardozo places his conclusion in the Meacham case upon the premise that an arbitration agreement relates to the remedy and is to be dealt with by the usual rule of the forum. But from the emphasis which he gives to the argument that it is undesirable that the clause in question should be enforced, it seems not to be doubted that the latter consideration, solely or predominantly, induced his conclusion and that his statement that the rule of the forum was applicable, because the arbitration provision is remedial, was merely an explanatory device or label. It is quite convincing to one who reads Judge Cardozo's opinion that his attitude toward the arbitration clause rests upon what is commonly called "policy," that is, his notion of expediency under the particular circumstances of the case at hand. Comparing a provision that submission of controversies to a foreign court shall be a condition precedent to recovery under a contract with a provision making submission to arbitrators a condition precedent, he said:

- "Indeed the considerations adverse to the validity of the contract are more potent in the latter circumstances, for in the one case we yield to regular and duly organized agencies of the state and in the other to informal and in a sense irregular tribunals. In each case, however, the fundamental purpose of the contract is the same- to submit the rights and wrongs of litigants to the arbitrament of foreign judges to the exclusion of our own. Whether such a contract is always invalid where the tribunal is a foreign court we do not need to determine. There may conceivably be exceptional circumstances where resort to the court of another state is so obviously convenient and reasonable as to justify our own courts in yielding to the agreement of the parties and declining jurisdiction. If any exceptions to the general rule are to be admitted, we ought not to extend them to a contract where the exclusive jurisdiction has been bestowed, not on the regular courts of another sovereignty, but on private arbitrators. Whether the attempt to bring about this result takes the form of a condition precedent or a covenant it is equally ineffective." $2 \tau$

The strength of his feeling against enforcing the arbitration clause in the case is all the more manifest when he says:

"Building contracts are made in New York to be performed all over the United States. If the judgment of the court below is to stand, jurisdiction over controversies arising under such contracts may be withdrawn from our courts and the litigation remitted to arbitrators in distant states." ${ }^{28}$

27 Ibid., 105 N. E. at 655 .

28 Ibid., 105 N. E. at 656. 
It is to be noted, also, that there is the same failure by Judge Cardozo clearly to distinguish domestic from conflict of laws cases as was criticized above in considering Judge Hogan's opinion. This appears from the following statement:

"It is true that some judges have expressed the belief that parties ought to be free to contract about such matters as they please. In this state the law has long been settled to the controry." 29 (Italics ours).

Judge Cardozo's explanation of the arbitration clause as remedial is as follows:

"An agreement that all differences arising under a contract shall be submitted to arbitration relates to the law of remedies and the law that governs remedies is the law of the forum. In applying this rule, regard must be had, not so much to the form of the agreement, as to its substance. If an agreement that a foreign court shall have exclusive jurisdiction is to be condemned, it is not saved by a declaration that resort to a foreign court shall be deemed a condition precedent to the accrual of a cause of action. A rule would not long survive if it were subject to be avoided by so facile a device. Such a contract, whatever form it may assume, affects in its operation the remedy alone. When resort is had to the foreign tribunal for the purpose of determining whether certain things do or do not constitute a breach, the cause of action must in the nature of things be complete before jurisdiction is invoked and cannot be postponed by the declaration that it shall not be deemed to have matured until after judgment has been rendered." 39

The implication seems to be that "the cause of action" necessarily is complete before the submission to the foreign court and that as it is then complete nothing can be added to "the cause of action" between that time and the time when the local court passes on the effect to be attached to the submission, tacitly assuming that all that occurs intermediately cannot possibly be substantive. From the standpoint of the foreign court, to which submission is made, "the cause of action," $i$. $e$., the operative facts to which the foreign court will or may attach certain legal consequences so far as it has power to do so, may include only events which have previously taken place; and yet "the cause of action" may include the additional facts of submission of the controversy to the foreign court and its decision or order. The statement as an argument seems at best merely a verbal one, but even if it could be said to have content or substance it is based on the erroneous assumption of the identity of "the cause of action" as respects the two tribunals involved. In spite of Judge Cardozo's declaration that the arbitration provision was purely "remedial" other portions of his opinion do reveal that

${ }^{29}$ Ibid., 105 N. E. at 656.

so Ibid., 105 N. E. at 655. 
unprocedural considerations actually had weight in inducing his conclusion in this particular case. This is apparent from his above comparison of submission to a foreign court with submission to private arbitrators and with court litigation, which has already been quoted, and especially from the following statement:

"The presence of the parties here, the ownership of property in this jurisdiction, these and other circumstances may make resort to our courts essential to the attainment of justice. If jurisdiction is to be ousted by contract, we may submit to the failure of justice that may result from these and like causes." ${ }^{11}$

Berkovitz v. Arbib \& Houlberg, Inc. ${ }^{32}$ included two cases, one of which brought up the question whether the New York Arbitrntion Law ${ }^{33}$ applied to contracts made but not litigated before the statute went into effect, while the other raised the question whether the Arbitration Law applied to cases as to which litigation had already been commenced at the time of its passage. The Arbitration Law was held to apply to the first but not to the second of these cases. The statutory sections involved were thus described by Judge Cardozo:

"Section $2 \ldots$ declares a new public policy and abrogates an ancient rule: 'A provision in a written contract to settle by arbitration a controversy thereafter arising ... or a submission hereafter entered into of an existing controversy to arbitration ... shall be valid, enforceable, and irrevocable, save upon such grounds as exist... for the revocation of any contract. ... Sections 3 and 4 prescribe the procedure for the enforcement of the contract and the naming of the arbitrator. Section 5 directs a stay of proceedings 'if any suit or proceeding be brought' when arbitration should be ordered." 34

Having set before himself the "new public policy" of New York toward arbitration agreements, Judge Cardozo draws upon a major premise under which a syllogism is readily constructed with a conclusion which states the result desired-that the statute applies in the case where litigation had not been commenced at the time that the statute was adopted. The major premise selected is that the rule of the forum is to be applied in determining questions which are remedial and under this is placed, as a minor premise, the proposition that whether an arbitration agreement is to be enforced or not is a remedial question, by

\footnotetext{
31 Ibid., 105 N. E. at 656.

32230 N. Y. 261,130 N. E. 288 (1921).

${ }^{33}$ N. Y. Cons. Laws (Cahill, 1923) 28.

34 Berkovitz v. Arbib \& Houlberg, Inc., supra note 32, at 269, 130 N. E. at 289. These sections have been copied in New Jersey, Massachusetts, Hawaii, and in the federal arbitration act. N. J. Laws 1923, c. 134; Mass. Acts 1925 , c. 294 ; HAW. REv. LAWS (1925) c. 171; 43 STAT. 883 (1925), 9 U. S. C. (1926).
} 
saying that "arbitration" is a form of procedure whereby differences may be settled," implying that it is nothing else:

"The common-law limitation upon the enforcement of promises to arbitrate is a part of the law of remedies. ... The rule to be applied is the rule of the forum.... Arbitration is a form of procedure whereby differences may be settled. It is not a definition of the rights and wrongs out of which differences grow. This statute did not attach a new obligation to sales already made. It vindicated by a new method the obligations then existing." 35

It has been pointed out that while arbitration is a method of settling controversies, it also affects substantially the legal consequences of the general bargain made by the parties to such an extent that the right to have the arbitration stipulation carried out may be and usually is regarded as vitally important. By the making of the agreement providing for arbitration certain legal consequences are stipulated for, including the right and duty to arbitrate. Judge Cardozo reveals the instrumental use of the term "lemedy" as a logical base, upon which the desired result may be set, in making the following statements:

"The word 'remedy' itself conceals at times an ambiguity, since changes of the form are often closely bound up with changes of the substance. ... The problem does not permit us to ignore gradations of importance and other differences of degree. In the end, it is in considerations of good sense and justice that the solution must be found. . . .

"Different considerations apply to the second of the cases ... To hold that the Arbitration Law of 1902 applies in such conditions is to nullify a cause of action by relation and by relation again to establish a defense. Years of costly litigation will thus be rendered futile. Nothing in the language of the statute gives support to the belief that consequences so harsh and drastic were intended by the Legislature." $s$ (Italics ours).

Here it serves Judge Cardozo's purpose, as to the result desired, not to treat the question of enforcement of the arbitration agreement as procedural or remedial alone, but as involving the "net substantive effect" ${ }^{3 \pi}$ resulting from application or non-application of the statute, $i$. e., in terms of legal "consequences harsh and drastic" and of nullifying "a cause of action" in the sense of destroying or changing existing legal relations. Likewise, "establishing of a defense" is spoken of as changing the legal relations between the parties.

The following statement shows that Judge Cardozo did not entirely overlook the difference between applying the arbitration statute in conflict of laws cases and applying it in domestic cases:

\footnotetext{
35 Berkovitz v. Arbib \& Houlberg, Inc., supra note 32, at 270, 130 N. E. at 289 .

${ }^{36}$ Ibid. 271-272, 130 N. E. at 290-291.

37 Cook, Equitable Defenses (1923) 32 YaLe L. J. 645, 653.
} 
"We do not now determine whether an arbitration clause, framed in contemplation of the statute in Great Britain, and calling for sessions of the arbitrators in London, is susceptible of enforcement under the statute of New York." ss

In United States Asphalt Refining Co. v. Trinidad Lalie Petroleum Co., Ltd., ${ }^{39}$ two actions were brought by a South Dakota corporation against a British corporation for alleged breaches of similar charter parties concerning vessels of British registry. Judge Hough noted in his opinion that the contract was made in England, and contained a clause, valid according to English law, providing for the settlement of disputes in London by arbitration. He reviewed many cases, however, most of which had no foreign elements or were treated as if only domestic facts were involved, and reached a conclusion apparently without having become aware that the instant case might be distinguishable because of the conflict of laws question involved. He had in mind the tacit assumption that, whatever might be the rule which should properly be applied in a domestic case, a similar rule should be applied in a conflict of laws case. If he can be regarded as having adopted any doctrine or rule of the conflict of laws, it would seem to have been either the rule that the lex fori determines questions of procedure, or the so-called "public-policy" doctrine." Most of Judge Hough's opinion consisted of the discussion or mention of some twenty decisions to show "the causes advanced for refusing to compel men to abide by their arbitration contracts," and dealt with this attitude of the courts entirely. It contained no treatment of the subject as a conflict of laws problem, and failed to distinguish the cases which involved such a problem as, for example, Hamlyn \& Co. v. Talister Distillery, ${ }^{41}$ the Meachom case ${ }^{42}$ and Gough v. Hamburg A. P. A., ${ }^{43}$ from cases in which no foreign element was involved.

\footnotetext{
- 38 Berkovitz . Arbib \& Houlberg, Inc., supra note 32, at 273, 130 N. E. at 291.

39222 Fed. 1006 (S. D. N. Y. 1915).

40 "The doctrine of public policy in the Conflict of Laws ought to have been a warning that there was something the matter with the reasoning upon which the rules to which it is the exception were supposed to be based. ... If some power other than that of state A prescribes for $A$ the rule that is to govern "on principle", if that rule is obligatory upon state A, how can state $A$ deny effect to such rule in a particular case? . . . Is it not strange to argue in the first place that state $A$ has no choice in accepting the original rule and then to admit that it has the power to set aside the effect of that rule whenever it pleases on the plea that such recognition or enforcement would violate its public policy?" Lorenzen, op. cit. supro note 6 , at 747 .

«I Supra note 8.

$\$ 2$ Supra note 22.

43158 Fed. 174 (S. D. N. Y. 1907), where the admiralty court refused to stay proceedings in accordance with a clause requiring all disputes to
} 


\section{Judge Hough said:}

"The question is one of remedy and not of right. Such was substantially the holding in Mitchell v. Dougherty and in Stephenson v. Insurance Company it is pointed out that: "The law and not the contract prescribed the remedy; and parties have no more right to enter into stipulations against a resort to the courts for their remedy, in a given case, then they have to provide a remedy prohibited by law." "sa

The former " of the two cases just mentioned was a domestic case and the latter ${ }^{45}$ was so treated, although it had extraterritorial elements. It is apparent, therefore, that the statement by Judge Hough, that the question at hand "is one of remedy and not of right," which he sought to support by the two cases last mentioned, was not apposite to the conflict of laws rule that remedial or procedural questions are to be determined by the lea fori. The next portion of the opinion, however, presents a sudden shift to use of the term "remedy" with reference to that rule:

"Finally it has been well said by Cardozo, J., in Meacham v. Jamestown etc., R. R. Co., that: "An agreement that differences arising under a contract shall be submitted to arbitration relates to the law of remedies, and the law that governs remedies is the law of the forum." " 17

This reference to the len fori seems to have been added merely to lend weight to a result reached upon a different ground. That ground-if conceived of from the standpoint of conflict of laws at all-seems to involve the so-called conflict of laws doctrine of "public policy," with a tacit assumption that the attitude to be assumed by a court toward an arbitration case in the conflict of laws must necessarily be the attitude the court would take in a similar case having no conflict of laws elements. Judge Hough then concludes:

"It follows that the final question for determination is whether the law as laid down by the Supreme Court of the United States permits the enforcement as a remedy of the arbitration clause contained in a contract; assuming that such clause (as here) is intended to oust the courts and all courts of their jurisdic-

be settled by a specified foreign court; cf. The Howick Hall, $10 \mathrm{~F}$. (2d) 162 (E. D. La. 1925), in which the court relied on Judge Hough's opinion in United States Asphalt Refining Co. v. Trinidad Lake Petroleum Co., Litd., supra note 39.

14 Supra note 39, at 1011. Note that at the time of this decision neither the New York Arbitration Law nor the United States Arbitration Act had been passed.

45 Mitchell v. Dougherty, 90 Fed. 639 (C. C. A. 3d, 1898).

46 Stephenson v. Insurance Co., 54 Mre. 55 (1866).

17 United States Asphalt Refining Co. v. Trinidad Lalte Petroleum Co., Ltd., supra note 39, at 1011. 
tion I think the decisions cited show beyond question that the Supreme Court has laid down the rule that such a complete ouster of jurisdiction as is shown by the clause quoted from the charter parties is void in a federal forum." 48

As none of the United States Supreme Court decisions cited by Judge Hough considered the question of enforcement of arbitration agreements otherwise than as a domestic question it is clear that these decisions could not logically be said to show what result the United States Supreme Court would reach in a conflict of laws case.

It was said by Judge Mack in a later case ${ }^{40}$ that the result in the Trinidad case "was reached ... because of what was assumed to be the public policy of the admiralty courts of the United States, the lex fori," but it does not seem possible to support any inference that the court sought to, ascertain such "policy" with the rule in mind that the lex fori is to be applied to determine questions of procedure.

In the Atlanten, ${ }^{50}$ the libelant, a Danish corporation chartered a steamer to the respondent, a corporation of Sweden, to proceed to the United States and to return to Denmark with a cargo. The charter party was executed in Denmark. While the steamer was on the way to the United States, the respondent repudiated the contract. The libelant sued to recover for the resulting losses and the respondent set up as a defense the failure to submit to arbitration as agreed. A decree was entered in favor of the libelant in the federal district court where Judge Learned Hand said:

"... under the law of Denmark and Sweden, arbitration is the condition precedent to any suit. ... Therefore it becomes necessary to determine whether the clause goes to the right or to the remedy and whether it is a condition precedent under our law if it goes only to the remedy.

"Such clauses, if regarded as conditions precedent to any action, have, I believe, nearly always been held to touch the remedy and not the right. ... They do not affect to touch the obligations of the parties, as surely they do not; they prescribe

${ }^{48}$ Ibid.; $c f$. Judge Cardozo in Berkovitz v. Arbib \& Houlberg, Inc., suprec note 32 , at $275,130 \mathrm{~N}$. E. at 292 : "In common language where no attempt is made at logical accuracy', it is sometimes said that the contract of arbitration 'ousts the jurisdiction' of the judges .... 'in strictness, however, it does not oust the jurisdiction, but merely introduces a new plea into the case' on which the judge as at common law, is under a duty to decide. . . . The situation is the same in substance as when effect is given to a releaso or to a covenant not to sue. Jurisdiction is not renounced, but the time and manner of its exercise are adapted to the convention of the parties restricting the media of proof."

49 Atlantic Fruit Co. v. Red Cross Line, 276 Fed. 319, 323 (S. D. N. Y. 1921).

50252 U. S. 313, 40 Sup. Ct. 332 (1919). 
how the parties must proceed to obtain any redress for their wrongs, which covers only remedies." :1

Judge Hand's argument that the arbitration clause goes "only to the remedy," seems to have been directed to the purpose of applying the rule that the lex for $i$ is appropriate to decide purely remedial questions. The decree was affirmed in the Circuit Court , of Appeals ${ }^{52}$ and on appeal to the United States Supreme Court was again affirmed. Justice Holmes said:

“. . . we agree substantially with the views of Judge Learned Hand in the District Court and Judge Hough in the Circuit Court of Appeals. Their opinion was that the owner repudiated the contract and that the arbitration clause did not apply.... such a refusal was not a 'dispute' of the kind referred to in the arbitration clause." $=3$

By adopting this view the Court avoided the question whether the Court would or would not determine the legal effect of the arbitration clause according to the domestic rule of the forum and whether the result would be explained upon the basis that the question determined was exclusively procedural.

The United States Supreme Court, in Red Cross Line v. Atlantic Fruit Co., ${ }^{51}$ came to consider whether or not to treat the specific enforcement of an arbitration agreement as exclusively procedural, though not with reference to the rule that the lex fori should be applied to procedural questions. The agreement involved was made before the New York Arbitration Law had been passed. Proceedings in the federal district court were brought after its passage but before decision of the New York Court of Appeals in Berkovitz v. Arbib \& Houlberg, Inc.s After that decision, the respondent, who had set up the non-compliance of libelant with the arbitration stipulation as a defense to the libel brought for alleged breach of contract, applied for an order in the Supreme Court of New York directing the libelant to submit the controversy to arbitration pursuant to the statute. Such an order was granted. This was affirmed by the Appellate Division and then reversed by the Court of Appeals. ${ }^{\circ}$ This last decision was then reversed by the United States Supreme Court.

The agreement had been executed in New York and pertained to the transportation of a cargo from New York to a port of

51 Aktieselskabet Korn-Og Foderstof Kompagniet v. Rederialtiebolaget Atlanten, 232 Fed. 403, 405 (S. D. N. Y. 1916).

52250 Fed. 935 (C. C. A. 2d, 1917).

53 The Atlanten, supra note 50 , at 315,40 Sup. Ct. at 333 .

54264 U. S. 109, 44 Sup. Ct. 274 (1924).

55 Supra note 32.

56 Matter of Red Cross Line, 233 N. Y. 373,135 N. E. 821 (1922), rcv'g 199 App. Div. 961, 191 N. Y. Supp. 949 (1st Dep't 1921). 
Newfoundland. It contained a provision for the settlement of any dispute that might arise between owners and charterers by arbitration in New York. The disposition of the application for specific enforcement of the arbitration clause involved Article III, Section 2 of the federal Constitution which provides, inter alia, that "the judicial power shall extend ... to all cases of admiralty and maritime jurisdiction ..." and section 256, clause 3 of the Judicial Code ${ }^{57}$ providing that the federal courts shall have exclusive jurisdiction, as to all civil admiralty and maritime cases. In reversing the decision of the Appellate Division, Judge Hogan speaking for the court said:

"Even if we assume that the proceeding is practically one to enforce specific performance of the arbitration clause of the contract an order granting such relief presupposes the existence of a controversy the subject-matter of which is within the jurisdiction of the court granting the order. ... The agreement to arbitrate ... is part of a maritime contract. ... Such clause is void in the federal forum.... To sustain the arbitration clause and enforce the same in the state courts would deny to the federal court the exclusive jurisdiction with which Congress has clothed it and likewise destroy a rule of uniformity."

It has been noted that in the Meacham case "Judge Hogan did not treat the question of enforcement of an arbitration clause as procedural, although Judge Cardozo did so treat it. Judge Hogan's statement, above quoted, could only be consistent, it would seem, with treatment of the question of specific enforcement as a substantive question. How otherwise could any order for specific enforcement relate to the "subject-matter" of controversy to be dealt with?

The term "subject-matter within the jurisdiction of the court" is meaningless unless, in the final analysis, legal consequences are referred to. Statements like those of Judge Cardozo in the Berkovitz case, extracting all content from the expected result of arbitration, are to be contrasted with statements like those of Judge Hogan just quoted; to observe how the judicial bottle labelled "arbitration" is now filled, now emptied, according to whether a full bottle or an empty bottle will make the decision appear more plausible. Judge Cardozo empties the bottle or else makes it appear empty by saying:

" "The rule to be applied is the rule of the forum. . . Arbitration is a form of procedure whereby differences may be settled. It is not a definition of the rights and wrongs out of which differences grow." 60

5740 STAT. 395 (1917), 28 U. S. C. § 371 (1926).

58 Supra note 56 , at 381,135 N. E. at 824 .

so Supra note 22.

${ }^{60}$ Berkovitz v. Arbib \& Houlberg, Inc., supra note 32, at 270, 130 N. I. at 289 . 
The statement that "arbitration is a form of procedure" is made with the negative inference that it is nothing else. This negation is then put in the next statement: "It is not a definition of the rights and wrongs out of which differences grow." And this statement is then left to stand as a denial of the function of the process, so as to present an assertion that since arbitration is procedure it does not define rights, etc. It could as easily and as plausibly be said that, "Litigation is a form of procedure whereby differences may be settled. It is not a definition of the rights and wrongs out of which differences grow"- thereby reaching the conclusion that right-duty or other legal relations are not defined or declared by the process of litigation. Thus, we should bring ourselves to deny that legal consequences are produced at all, by denying that the terms, which we use to describe legal consequences, describe anything.

In Red Cross Line v. Atlontic Fruit Company, ${ }^{612}$ the United States Supreme Court, in reversing the New York Court of Appeals, found it convenient to treat the New York Arbitration Law, and so arbitration itself, as remedial purely and not substantive. Justice Brandeis, speaking for the court, said the statute dealt "merely with the remedy in the state courts (without attempting) either to modify the substantive maritime law or to deal with the remedy in courts of admiralty."

Justice McReynolds dissenting remarked:

"No admiralty court would enforce the arbitration clause of the charter party before us; their accepted policy forbids. Accordingly it was not obligatory upon the parties. The law of the sea becomes part of their agreement. But it is said under the local law, a state court may enforce arbitration and thus effectuate the provision, although unenforceable in admiralty, since the statute related to the remedy and not to substantive rights. ... Under the guise of providing remedies no state statute may add to or take from the obligations imposed by the contract within the admiralty jurisdiction." 62

In the litigation of Atlantic Frutit Co.v. Red Cross Line in the federal court, ${ }^{03}$ libelant's failure to submit to arbitration was not recognized as a defense. Judge MIack, quoted Judge Cardozo in the Berliovitz case, ${ }^{04}$ and placed the decision upon the ground that: "Arbitration statutes or judicial recognition of the enforceability of arbitration provisions do not confer a substantive right, but a remedy only." ${ }^{5}$

Judge Hough in the Circuit Court of Appeals, in affirming the decision of the district court said that although the New York

\footnotetext{
61 Supra note 54, at 124, 44 Sup. Ct. at 277.

E2 Ibid. 126, 44 Sup. Ct. at 278.

63 Supra note 49.

64 Supra note 32.

$\approx$ Atlantic Fruit Co. v. Red Cross Line, stpra note 49 , at 323.
} 
Arbitration Act afforded a remedy in this instance the statute had no effect upon "whatever remedy the admiralty offered." oo

The opinion of Judge Mack in the lower court indicates that the decision of that court was reached after a good deal of reluctance, for he said:

"I recognize the growing sentiment in the commercial world, ... that the law ought not to interfere and render arbitration agreements ineffective. ... Arbitration clauses are found in virtually all the standard forms of charter parties and are particularly favored by shipping men as a means of avoiding litigation in distant countries before foreign tribunals. It is, moreover, important that in these matters American maritime law should accord with that of the other great maritime countries. Nor should it be overlooked that an unfortunate situation is created if arbitration agreements can be repudiated in American courts while American citizens can insist upon their enforcement in their favor as a bar to litigation abroad... . Nevertheless, sitting in this circuit, I am constrained to follow the decisions in the Atlanten and the Eros. . ."

Judge Hough in his opinion in the Circuit Court of Appeals commented as follows upon the decision of the United States Supreme Court in Red Cross Line v. Atlantic Fruit Co. ${ }^{\text {ss }}$

"It is strenuously urged that the arguments presented at this bar when The Atlanten was before us ... and in the Eros have now received such additional strength by the decision of the Supreme Court in Red Cross Line v. Atlantic Fruit Company that it is our duty to ... hold that the second defense was good.... We are asked to assume that the Supreme Court, without the compulsion of any statute, is now ready to hold that in proceeding upon an executory contract containing an agreement to arbitrate any and all disputatious matters arising therefrom, no action would lie upon an arbitrable dispute, if the party sued pleads (as here) the arbitration clause and willingness to abide thereby. ... The point has been conveniently presented before now to the Supreme Court. The appeal in The Atlanten ... afforded an opportunity which was confessedly avoided. The refusal to enforce executory agreements to arbitrate disputes still continues and it is not only permitted, but generally believed to be required by the decisions of the Supreme Court, if adherence to the spirit as well as the letter of controlling opinion by loyal obedience to the precedent system. This particular charter party called for arbitration in New York. . . . The majority of such charters are drawn with provisions for arbitration in London and with an eye to the existing arbitration statutes of Great Britain. Very wisely, the New York Court of Appeals called attention to this difficulty in Berkovitz v. Arbib \& Houlberg and especially reserved the question (not yet presented) whether the New York statute can or should be so read as to cover arbitrations in foreign parts." 6

${ }_{66}$ Atlantic Fruit Co. v. Red Cross Line, 5 F. (2d) 218 (C. C. A. 2d, 1924).

67 Supra note 49 , at 322 .

68 Supra note 54.

e9 Supra note 66 , at 220 . 
In the case of the Eros, ${ }^{70}$ a libel was brought for alleged breach of a time charter entered into at Paris, relating to a yacht of French registry flying the French flag. The libelant was an American citizen residing in Paris. The owner was a French citizen residing in Paris and his interests were asserted in the name of the master, as claimant. The yacht was chartered to libelant to be delivered with master and crew for libelant's use at New York, where she arrived July 27th, 1914. While minor repairs were being made, war was declared between France and Germany and the master, under orders from the owner, refused to proceed on the ground that some of his crew were subject to call for French war service. Such members were afterwards discharged and after some days of negotiations, the master under instructions of the owner, refused to fill the crew or move from the port, even within waters of the United States, and declared that "the whole thing is all off," whereupon libelant procured another yacht. The yacht was not requisitioned by the French government. The charter contained a provision that any dispute should be submitted to arbitration and that, "This agreement to be construed according to English law." Claimant contended that the action should be dismissed until arbitration as provided for had been had or had failed. In rendering a decree for libelant, Judge Veeder said:

"If such a general arbitration clause would ever apply to a repudiation of the agreement ... it is clear that it goes to the remedy, not to the rights, of the parties, and that its effect is to be determined by the law of the forum. And in this forum it is well settled that such a general arbitration clause is ineffective to deprive the parties of their right to appeal to the courts. ..." ${ }^{71}$

It seems quite obvious that the provision for construing the agreement according to the law of England was an attempt to select one set of legal consequences as against another. To the extent that its decision imposes another, differing set of legal consequences the court would surely seem to be determining a substantive question independent of the meaning to be given to the words of the agreement.

The provision quoted would seem unnecessary and superfluous if it does not declare a selection of "English" as against other possible legal consequences. The court brushes aside this phase of the case, however, to treat the question of enforcement of the arbitration agreement as procedural in order to avoid giving the agreement effect, preserving alignment with the previous federal decisions cited in support of the conclusion. On appeal to the federal Circuit Court of Appeals, the decree for the libelant

70241 Fed. 186 (E. D. N. Y. 1916).

71 Ibid. 191. 
was affirmed by Circuit Judges Ward and Hough and District Judge Learned Hand, in a per curiam opinion which declared that, "the provision as to arbitration is not enforceable in our courts." 72

Two recent decisions have treated the question of the enforcement of an arbitration award as substantive, applying the rule of the "place of making" of the agreement (lex loci contractus). Taylor $v$. Basye ${ }^{73}$ dealt with the question of enforcement of an arbitration award rendered outside of the state of Washington but which, if it had been rendered within that state, would not have been enforced for lack of fulfilment of the Washington statutory requirement that an award be recorded and entry of judgment made thereon. ${ }^{74}$ The arbitration provision was part of an agreement entered into in Oregon, the subject matter of which embraced a lease of land situated in Washington and certain other personal property. The court said:

“... an agreement for arbitration made in this state is without effect unless it complies with our statute. ... It is admitted that this award is good, as a common law award and legal under the laws of the state of Oregon, where it was made, and it seems to be sufficient in all respects to comply with the law of this state except that it was never made a matter of record, nor judgment entered upon it as our laws prescribe. The parties entering into the agreement were both in the state of Oregon. The subject matter embraces a lease which under our laws is a chattel interest ... and certain other personal property concerning which the parties were free to contract irrespective of where it was situated.

". . a contract good in the state where it is made can be enforced in another state even though it is not executed with the formalities required in the latter state. .." 75

The court, referring to two early cases, called attention to the fact that the rule just stated had been applied to arbitration agreements. Green v. East Tennessee \& Georgia R. $R .^{7^{\circ}}$ had upheld an award on the ground that, "The contract containing the agreement to refer was a Tennessee contract and as such its validity and construction in the Courts of Georgia depended upon the laws of Tennessee." There is nothing to indicate that the possibility of regarding the question as procedural, to be disposed of according to the rule of the forum, was thought of. Titus $v$. Scantling ${ }^{77}$ had upheld an award made pursuant to a certain bond whereby defendant undertook to pay the amount which should be awarded by certain arbitrators. The bond was

72251 Fed. 45 (C. C. A. 2d, 1918).

7.3 119 Wash. 263, 205 Pac. 16 (1922).

74 WASH. Comp. STAT. (Remington, 1922) $\$ \S 420$ et seq.

75 Taylor v. Basye, supra note 73, at 265, 205 Pac. at 16.

${ }^{76} 37 \mathrm{Ga} .456$ (1867).

- ${ }^{7} 4$ Blackf. 89 (Ind. 1835). 
executed in Ohio and "was to be there complied with" both as to the making of the award and as to payment of the amount awarded. Whether the award was actually made in Ohio or Indiana does not appear. The court held the award valid under the Ohio rule, saying that the result should be the same were the Indiana rule to be applied. The court did not make any differentiation between the treatment of arbitration provisions and the treatment of contract provisions in general in conflict of laws cases.

In Fisher Flouring Mills Co. v. United States, ${ }^{35}$ arbitration was agreed upon after a dispute had arisen. The federal district court held the award valid, although it had not been "filed in the office of the clerk of the Superior Court of the county wherein the arbitration" was held or entered on the records of the court and affirmed by the court as a judgment, as the Washington arbitration statute required in order to make it "conclusive." In reversing the judgment rendered in favor of the United States, Rudkin, J., said:

"The agreement to submit to arbitration was made in (Washington), the arbitration took place there, the award was made there, and the validity and effect of the award must be determined by reference to its laws." :

The decision in the case of The Silvcrbrook, ${ }^{69}$ holding the United States Arbitration Act of $1925^{\mathrm{si}}$ inapplicable to an arbitration agreement which provided that the arbitration should take place in England was, in the writer's opinion, very unfortunate. A charter party between an English corporation and the claimant, an American corporation, stipulated for a voyage from London to New Orleans, and provided that any disputes were to be settled by arbitration in London. The libelant, the holder of bills of lading (into which the charter party was incorporated by reference), filed a libel in rem for damages to the cargo. The claimant sought to stay the proceedings on the ground that the contract sued on constituted a maritime transaction or contract involving commerce within the terms of the United States Arbitration Act. The motion for a stay of the suit was denied, Judge Burns saying:

"It is plain enough that Congress intended to abolish the old rule, ... by which the federal courts refused to enforce arbitration agreements. But ... the act seems to contemplate only such arbitration agreements as would be or could be carried out in the United States, within the jurisdiction of and under the control and orders of the United States Courts....

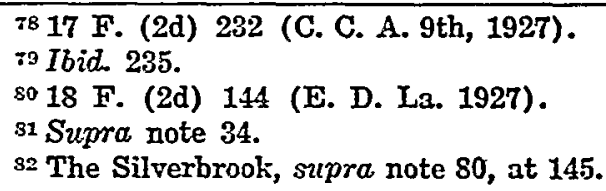


"My conclusion seems fortified by the terms of each of these sections, which clearly contemplate what in effect amounts to a judicial enforcement of specific performance of arbitration clauses ... the courts of the United States, necessarily, however, confining these courts within the legitimate bounds of their territorial jurisdiction. . . . This court is without jurisdiction to direct the parties to proceed to arbitration as required by the concluding clause of (Section 8) because the place and manner of arbitration prescribed by the terms of the contract are beyond the jurisdiction of this court since the hearings and proceedings thereunder cannot be held conformably to the terms of this statute, and particularly to Section 4 , which requires the arbitration to proceed within the district in which the petition for an order directing such arbitration was filed. This court cannot direct and otherwise supervise and conclude an arbitration to be held in London, or assume to vacate, modify, or correct any award that might be made there, or indeed anywhere, except within this district, nor has it power as a court of admiralty to arbitrarily reform or modify the terms of the contract by ordering an arbitration elsewhere or otherwise than agreed upon by the parties."

Having concluded that the statute was inapplicable to this particular case, the court refused specific enforcement of the arbitration stipulation upon the assumption that the statute not being applicable, no other result could justifiably be brought about in view of the previous federal decisions. It is submitted, however, that this assumption was mistaken and that upon more thorough analysis of the case as a problem in the conflict of laws a decision specifically enforcing the arbitration agreement could have and should have been made.

It is evident that the result arrived at issued from the fundamental postulate in the mind of the judge as to the nature of any problem in the conflict of laws, that any such problem resolves itself into ascertaining what state or country has "jurisdiction" in the sense of exclusive power to determine for all states or countries the rule of law to be applied to the given factual situation. This is on the basis "that for every situation dealt with in the conflict of laws there is always some one and only one 'law' which has 'jurisdiction', i.e. power, to determine what legal consequences shall be attached to the given situation," ${ }^{33}$ with the assumption which usually inheres in such

\footnotetext{
83 "Rights being created by law alone, it is necessary in every case to determine the law by which a right is created. ..." BEALE, SUMMAIIY of THE CONFLICT OF LAWS (1902) § 41.

"Some proper law must have governed the juridical situation at the moment of its occurrence; the effort of the court is to determine what that law was; and that is the question of the power of some particular law to extend to and rule the juridical situation." BEALE, CoNFLICT OF LAwS (1916) 1.

"The branch of the law called for convenience THE Confuct of LAws deals primarily with the application of laws in space. Whenever a quastion
} 
a view (unless the other horn of this dilemma, acceptance of the renvoi doctrine, is chosen) - the assumption that the rule to be adopted in a conflict of laws case is identical with the domestic rule of the state or country regarded as having "jurisdiction" in the sense explained. The latter assumption is appar-

is raised of applying to a juridical situation the law of one or another country, the question so raised must be settled by the principles of the Conflict of Laws." Ibid.

"A right having been created by the appropriate law, the recognition of its existence should follow everywhere. Thus an act where done cannot be called in question anywhere. ... This is true even if the right so created is absolutely illegal in the other State." Beale, Sumarary of the Co:FLICT OF LAWS (1902) § 47.

"For the creation of rights there must exist some law with power to create them, or in the ordinary phrase, with jurisdiction." Ibid. $\$ 6$.

"It is impossible that a single event should be followed by two contradictory consequences. Only one law, therefore, can have jurisdiction." Ibid. $\S 11$.

"The topic called 'Conflict of Laws' deals with the recognition and cnforcement of foreign created rights." Ibid. $\$ 1$.

Note how all juristic meaning in the sense of connotation of legal consequences is taken from the terms "creation" and "recognition," as applied to rights, in the following statements by which the existence and estent of "rights" as legal consequences are treated as depending finally, if not entirely, upon "enforcement," although it seems, according to Eeale, that a "right" must be first "created" by "the proper law" before there can be "enforcement" of it, viz.: "Though a foreign right must be recognized as existing, it does not follow that it will be given any legal force. Since a right can have no legal force unless it is given force by law, and since nothing can have the force of law in a State except the law of that State, it follows that no foreign right can be enforced unless the law of the State so provides. This depends on the law as to the enforcement of foreign rights." Ibid. \$ 48. "But since the enforcement comes through the domestie law, that law may refuse to give any effect to the right." Ibid. $\$ 49$. In view of the latter statements, is it a workable explanation to say, as Professor Beale does, that, "The primary purpose of law being the creation of rights ... the chief task of the Confict of Laws (is) to determine the place where a right arose and the law that created it."? Beacs, Cosifucr of LAWs (1916) § 139 . Is it convenient or necessary to use the term "right" with such shifting connotation as sometimes to give it a meaning signifying legal consequences and at other times to withdraw that meaning, transferring the connotation of legal consequences entirely into the term "enforcement"? To speak of a "right" as being "created" with respect to a particular court and then to say that that court must "recognize" it although the court need not or will not "enforce" the so-called "right," does not seem to be useful in the description or prediction of what a court will do in a given case and only calls in an unreal phantom which is an intruder so far as the thought processes are concerned. Using the term "right" to describe what courts or other societal agents will actually do, is it not a clearer and more accurate description of what happens to acknoviledge that in conflict of laws cases, apart from constitutional limitations, "each state has the power to attach different legal consequences to a particular group of operative facts" although "it would be highly inconvenient as well as unjust if the power were exercised in every instance" [Lorenzen, The Theory of Qualifications and the Conflict of Lavs (1920) 20 CoL. L. REv. 
ent in the statement of Judge Burns that before the federal Arbitration Act was passed "arbitration agreements of this character were void," making no distinction between domestic and conflict of laws cases, as it is also apparent in his explana-

247, 279] and to explain what is done thus: "The forum, when confronted by a case involving foreign elements, always applies its own law to the caso but in doing so adopts and enforces as its own law a rule of decision identical, or at least highly similar though not identical in scope with a rule of decision found in the system of law in force in another state or country with which some or all of the foreign elements are connected, the rule so selected being in normal cases and subject to (exceptions) the rule of decision which the given foreign state or country would apply, not to this very group of facts now before the court of the forum, but to a similar but purely domestic group of facts involving for the foreign court no forcign element. ... The forum thus enforces not a foreign right but a right created by its own law." Cook, op. cit. su!pra note 6, at 460-470. As Professor Corbin puts it very concisely: "Each jurisdíction, in so far as it is politically independent, can and does choose the rule that it sees fit and thus the court of the forum makes for itself, its own law in each case." ANson, Contracts (Corbin's 4th ed. 1924) 110. Compare the following statements by Judge Learned Hand: "No court can enforce any law but that of its own sovereign." Guinness v. Miller, 291 Fed. 769, 770 (D. C. 1923). "I can only follow the law of the place where I sit. . . No court can enforce the law of another place." Direction der Disconto-Gesellschaft v. U. S. Steel Corp., 300 Fed. 741, 744 (D. C. 1924).

It is only because a conflict of laws case is seen to be different from a domestic case so that no domestic rule is applicable in itself, that any problem in conflict of laws is or can be recognized. Yet the theory that tho "Conflict of Laws deals with the recognition and enforcement of foreigncreated rights" or "with the application of laws in space" is inconsistent with the very hypothesis upon which the recognition of the presence of a problem of conflict of laws, as distinct from a domestic problem, depends. The method which this theory leads to is misleading not only in the treatment of so-called substantive questions but also in the treatment of questions taken to be procedural and placed under the rule that "the lex fori determines questions of procedure." In this regard the danger is that the proper application of the rule, as merely signifying that changes of machinery of the court of the forum will not be made in a conflict of laws case, will be lost sight of and that questions which should be treated as substantive, either wholly or partly, will be treated as merely procedural and mochanically relegated to some domestic rule of the forum-treating the factual situation as having created merely a logical problem and excluding all economic and social considerations. This, it is believed, has been the effect or tendency of this method in the treatment of arbitration cases, discussed above, in several instances, if not in every instance in which the question of whether or not an agreement to arbitrate disputes should be enforced was treated as "governed by the law of the forum" upon the ground that it related to "procedure" or "remedy." For example, in the following statement Judge Hough clearly seems to take the view that the subject of conflict of laws deals with the operation of law in space, in the sense that the problem in each case is that of identifying "the proper law" having territorial "jurisdiction," i. e., exclusive power to determine the legal consequences of a factual situation: "What New York and other courts regarded as the 'common law limitation upon enforcement of promises to arbitrate' was a part of the law of remedies, which is a portion of the law 
tions of the decisions in the cases of The Eros ${ }^{\text {st }}$ and Cait'd States Asphalt Refining Co. v. Trinidad Lalie Petrolcum Co. Thus Judge Burns, in explaining the decision in the case of The Eros, apparently regarded it as imperative that whatever rule the court of the forum would apply in the normal domestic case must be applied in a conflict of laws case. The same idea stands out strongly in the interpretation by Judge Burns of Judge Hough's opinion in United. States Asplalt Refining Co. $v$. Trinidad Lake Petroleum Co., and the application of his interpretation to that case, which involved a quite similar arbitration agreement.

His explanation first states the conflict of laws rule:

"The decision was to the effect that an agreement in a contract that differences arising thereunder shall be submitted to arbitration relates to the remedy and the question whether such an agreement was enforceable was governed by the rule of the forum." se

He then announces as the rule of the forum to be employed in the foregoing conflict of laws formula the ordinary domestic rule of the forum (that is a rule conceived apart from any conflict of laws problem), saying that the decision was also

"... to the effect that a provision in a charter party made in London that 'any dispute arising under this charter shall be settled in London by arbitration . .. and this decision shall be binding upon both parties' was an agreement for arbitration applied to the whole contract and while valid under the English Arbitration Act of 1889 , it was void in a federal forum." s:

That Judge Burns, like Judge Hough, merely had in mind the domestic rule without regard to the conflict of laws elements or phases is clear from his remark that,

"Judge Hough carefully reviewed the existing jurisprudence and concluded that the doctrine was settled by the Supreme Court; that is, that where such clauses in contracts operate a complete ouster of the jurisdiction of the courts they should be held void in a federal court." ss

It will be recalled that Judge Hough in United States Asphalt Refining Co. v. Trinidad Lake Petrolcum Co., ${ }^{\mathrm{b9}}$ after remarking near the end of his opinion, "Furthermore the question is one

of the forum," inferring that there are other "parts" of the law which are "portions" of some other "law" than that of the forum. Atlantic Fruit Co.

v. Red Cross Line, supra note 66 , at 219.

84 Supra note 70.

so Supra note 39.

86 The Silverbrook, supra note 80 , at 145 .

s? Ibid.

88 Ibid. 149.

so Supra note 39. 
of remedy and not of right," ${ }^{\infty}$ quoted Judge Cardozo to the effect that an arbitration agreement "relates to the law of remedies and the law that governs remedies is the law of the forum," and then said:

"It follows that the final question for determination . . . is whether the law as laid down by the Supreme Court of the United States permits the enforcement as a remedy of the arbitration clause contained in a contract. ... I think the decisions cited show beyond question that the Supreme Court has laid down the rule that such a complete ouster of jurisdiction as is shown by the clause quoted from the charter parties is void in a federal forum." 92

The "decisions cited" to which he refers were nearly all domestic cases or were so treated, as has been pointed out above, and the one or two conflict of laws decisions which were cited were mentioned indiscriminately along with the domestic decisions and entirely without regard to their conflict of laws aspects. Hence they could not be said to be precedents in conflict of laws cases. It will be recalled also that it was Judge Hough himself, who in an opinion written nine years later expressly called attention to the fact that the United States Supreme Court had never undertaken to decide the question of specific enforcement of an arbitration agreement as a matter of the conflict of laws. ${ }^{25}$

So far as the decision in United States Asphalt Refining Co. $v$. Trinidad Lake Petroleum $C^{0 .} .^{93}$ is concerned, whether the decision as a conflict of laws decision is ascribed to the rule that procedural questions should be determined according to the lex fori or to the so-called "public policy" doctrine, it is clear that the decision was reached by treating the conflict of laws rule as necessarily identical with the domestic rule which had become established in federal cases.

It is believed, therefore, that the decision in the case of $T$ the Silverbrook ${ }^{24}$ rested upon an assumption that, apart from the United States Arbitration Act, the conflict of laws rule as to the enforcement of arbitration agreements depended upon and was necessarily identical with the domestic rule in the federal courts. It is submitted that, conceding that the Arbitration Act did not cover this particular situation, it did, at least, do away with the former domestic rule in admiralty for the federal courts, establishing a new domestic rule, if not also a conflict of laws rule as to such arbitration agreements as could be carried out in the United States. Consequently, even upon the assumption by

00 Ibid. 1011.

Q1 Ibid.

32 Atlantic Fruit Co. v. Red Cross Line, supra note 66, at 220.

93 Supra note 39.

34 Supra note 80. 
the court that the conflict of laws rule should be identical with or similar to the domestic rule or upon the adoption by the court of the same method of arriving at a decision as it supposed itself to be employing, should not the court have enforced the arbitration agreement in accordance with the policy of the statute, although the statute by its own force may not have been strictly applicable?

In the instance afforded by this particular case a desirable result from a commercial standpoint might conceivably have been attained by the purely mechanical method outlined above. But proceeding from the postulate that a problem in conflict of laws is merely a problem of spacial "jurisdiction," the probabilities are that an unsatisfactory commercial result would be reached by the decision, because the pursuit of such a method ignores economic and social factors arising from the interstate or international phases of the situation.

The decision in The Silverbrook,95 rendered in Mirch, 1927 was overruled, however, in October of the same year in Daniclsen. v. Entre Rios, ${ }^{96}$ insofar as the court in the earlier case had "refused a stay of trial, holding that the act had no application to contracts for arbitration performable outside the United States." ${ }^{97}$ A clause providing for "arbitration in London in the customary manner" was included in a charter party entered into in London between the agents of South American charterers and the master of a Norwegian vessel for the carriage of coal from Baltimore, or a nearby port, to South America. The libel was brought to recover for delay caused by failure of the charterers to notify the master before his arrival at what port he should load. It was held in accord with the decision in the case of The Fredensbro, ${ }^{\text {s }}$ involving an arbitration clause of precisely the same kind and a similar set of facts, that the arbitration clause "did not form a basis for excepting to the jurisdiction of the court," but that the act "requires the courts to stay trial, upon motion of one of the parties, until arbitration is had, and to order arbitration if, as provided in section 4, the hearing and proceedings under such agreement shall be within the district in which

\section{Ibid.}

se 22 F. (2d) 326 (D. Md. 1927).

si In Lappe v. Wilcos, 14 F. (2d) 861 (N. D. N. Y. 1926), it was held that the New York Arbitration Law was not applicable to non-residents of $\mathrm{New}$ York and motion to stay the action under the statute mas denied. Plaintiff and defendant, residents of Pennsylvania and New York, respeetively, had made an agreement in New York which provided for arbitration. The court based its decision on the ground that the New York statute was remedial and could not affect a non-resident so as to preclude him from suit in a federal court. Note that the court treats the question as procedural although it speaks of "the rights" of non-residents to resort to the federal courts. See Note (1928) 28 CoL. L. REv. 472.

98 18 F. (2d) 983 (E. D. Pa. 1927). 
the petition for an order directing such arbitration is filed." The court declared that "the proceedings may be brought in the usual manner and jurisdiction over the arbitration assumed if the arbitration provided for is to take place within the court's jurisdiction; if not, then the proceedings shall be stayed until the foreign arbitration is perfected, whereupon the court has power to enter a decree upon the award." ${ }^{100}$ Judge Coleman said:

"The language of these sections 101 makes it evident that the intent of Congress was to change the existing rule and make contracts for arbitration effectual.... (The holding in The Silverbrook) seems erroneous under the broad language of section 3 granting that section 4 of the act limits the jurisdiction of the court to order arbitration in connection with agreements performable within the United States. ... The express purpose of the act is to deal with disputes in matters not merely of domestic, but of foreign, business, commerce 'with foreign nations,' which implies that the incident of such commerce which the act validates-that is arbitration-occur in foreign places." 10a (Italics ours).

We have seen that in the English cases involving the enforcement of arbitration agreements, since the enactment of the English Arbitration Act of 1889, the question of enforceability has not been treated as procedural. There was no occasion for their so doing in order to insure the application of the domestic rule through employment of the conflict of laws rule that "the lex fori determines questions of procedure." In American cases, decided apart from modern arbitration statutes changing the domestic rule of the forum, the device was, on the other hand, quite commonly availed of to hold arbitration provisions inoperative. Where the local rule of the forum, by statute or otherwise, has sustained arbitration provisions, the rule that "the lex fori determines questions of procedure" has not noticeably been called 'upon. Now that statutes favoring arbitration are becoming more general, it is to be expected that the application of this rule with treatment of arbitration as "procedural" will become less and less frequent. This use of the term and of the rule seems to furnish a strong illustration that:

09 Danielsen v. Entre Rios, supra note 96, at 327.

100 Ibid. 327-328.

101 U. S. Arbitration Act 1925, §§ 2, 3; 43 STAT. 883 (1925), 9 U. S. C. $\S \S 2,3$ (1926). Section 2 provides that "a written provision in any maritime transaction or a contract evidencing a transaction involving commorce, to settle by arbitration a controversy" etc. "shall be valid, irrevocable and enforceable, save upon such grounds as exist . . . for revocation of any contract.". Section 3 provides that "if any suit or proceeding be brought ... . upon any issue referable to arbitration ... . the court shall on appli. cation ... stay the trial . . . until such arbitration has been had in accordance with the terms of the agreement ..." (Italics ours).

102 Danielsen v. Entre Rios, supra note 96, at 328. 
"Behind the logical form (of judicial decision) lies a judgment as to the relative worth and importance of competing legislative grounds, often an inarticulate and unconscious judgment, it is true, and yet the very root and nerve of the whole proceeding. You can give any conclusion a logical form." 103

103 Holnies, Collected Legal Papgrs (1921) 181. Cf. Devey, Logical Method and the Law (1924) 10 ConN. L. Q. 17, 21: "While the syllogism sets forth the results of thinking, it has nothing to do with the operation of thinking."

While the writer is solely responsible for the views expressed, he gratefully ackmowledges his indebtedness to Professors Lorenzen and Sturges for the help of their criticisms and his indebtedness to Professor W. W. Cook for any usefulness that this article mag have from the standpoint of conflict of laws analysis. 